\title{
KONFLIK KOMUNAL DAN RESOLUSI DAMAI STUDI KASUS DI KALIMANTAN TENGAH
}

\author{
M. Shohibul Hidayah \\ Universitas Islam Indonesia
}

\begin{abstract}
Abstrak
Tulisan ini bermaksud menelaah lebih mendalam akar konflik horisontal bemuansa etnis yang terjadi di Kalimantan Tengah sekaligus mencari resolusi yang tepat. Kalimantan Tengah memiliki pluralisme suku yang hidup didalamnya, diantaranya suku Dayak, Arab, Banjar, Bugis, Jawa, Cina dan Madura. Pluralisme suku ini menyebabkan terjadinya gesekan kultural yang berakhir dengan kerusuhan sosial. Selain akibat gesekan kultural tersebut, laklor lain yang ikut menjadi penyebab terjadinya kerusuhan sosial tersebut adalah faktor struktural, politik, sosial, dan ekonomi. Salah safu konflik besar yang terjadi belum lama in adalah konfik antara etnis Dayak dan etnis Madura yang bemula dari perkelahian antar pemuda. Solidaritas dan balas dendam kesukuan muncul karena pada konllik tersebut tejadi pembunuhan. Prinsip-prinsip adat turt mempengaruhi berkecamuknya konflik sehingga menjadi berkepanjangan. Berbagai pola resolusi konflik tengah diupay akan oleh pemerintah demi terwujudnya perdamaian dan altematif negosiasl menjadi pilihan terbalk yang strategis untuk menyelesaikan konflik.
\end{abstract}

Kata-kata kunci: konflik, etnis, pola resolusi.

\section{PENDAHULUAN}

$\mathbf{M}$ anusia memiki naluri untuk hidup bersama dengan manusia lainnya (hu(man relationship). Rumusan-rumusan yang indah tentang manusia sebagai makhluk rasional (animal rational) dan makhluk berbudaya melekat dalam labirin kognitif kita. Manusia juga memiliki keistimewaan dibanding mahluk lainnya, kemulian yang dimiliki manusia (human dignity) dilihat dari konstruksi peradaban manusia yang monumental seperti gedung-gedung megah, alunan musik yang indah, ilmu pengetahuan dan teknologi melainkan juga meninggalkan jejak kerusakan lingkungan hidup, korban peperangan, dan berbagai kerusakan lainnya. Tidak mengherankan jika Sigmund
Freud, pakar Psikoanalisa beranggapan bahwa tingkah laku manusia sebagian besar didorong oleh alam bawah sadar, atau kekuatan ldyang cenderung merusak. Sikap antogonistik manusia ini adalah cerminan dari berakarnya naluri kematian (thanatos).

Konfilk sosial dan perilaku kekerasan yang terjadi di Indonesia, sepuluh tahun belakangan ini menjadi tema sentral yang menarik perbincangan berbagai kalangan masyarakat, baik masyarakat nasional maupun masyarakat intemasional. Wacana kekerasan yang meledak tersebut mencengangkan mata dunia tentang wajah baru bangsa Indonesia. Wajah penuh ketegangan dan konflik kekerasan yang menyebar di seluruh penjuru tanah air. 
Wabah sosial borkepanjangan yang telah menelan ratusan ribu korban jwa rakyat $h$ donesia tak berdosa.

Perilaku antagonis yang muncul di selasela proses interaksi sosial antar entitas anak bangsa tersebut, seketika muncul ke permukaan, menggugat identitas kultural yang justru selama ini tidak pernah dipermasalahkan. Papua, Aceh, Ambon, Sambas, merambat sampai ke Sampit yang dianggap sebagai malapetaka terbesar anak bangsa. Ribuan korban jiwa yang tak berdosa jatuh dari kedua belah pihak yang bertikai, sementara ratusan ribu lagi merana dalam kehidupan yang tidak pasti oi pengasingan.

\section{HETEROGENITAS ETNIK DI KALIMANTAN TENG AH}

Kalimantan Tengah dikenal sangat heterogen. Bebeda dengan propinsi-propinsi yang lain, heterogenitas etnk of Kalimantan Tengah disebabkan oleh adanya proses migrasi yang masuk dari berbagai kelompok etnik yang berbeda diseluruh wilayah nusantara. Kalimantan Tengah dihuni beberapa kelompok etnik, yang telah melakukan akulturasi dan pembauran cukup lama dalam suasana pergaulan sosial multietnik yang rukun dan harmonis. Indikator keharmonisan masyarakat Kalimantan Tengah ini dapat dilihat dari pesatnya kemajuan pembangunan yang dicapai propinsi termuda di Kalimantan. Menunut Herskovits, Linton \& Redfield (dalam Berry, dkk, 1999)
Akulturasi adalah fenomena yang akan terjadi tatkala kelompok-kelompok individu yang memiliki budaya berbeda teribat dalam kontak yang berlangsung secara nyata yang disertai perubahan terus-menerus, sejalan dengan pola budaya asal dari kelompok itu atau dari dua kelompok tersebut. Potret masyarakat multkultural di Kalimantan Tengah dapat dilihat dari pluralisme suku yang hidup didalamnya, di antaranya suku Dayak, Arab, Banjar, Bugis, Jawa, Cina dan terakhir Madura. Kehidupan masyarakat Kalimantan Tangah dalam pergaulan sosial multi-etnik tergambarkan dalam struktur relasi sosial yang dinamis antar kelompok etnis baik di bidang politik, ekonomi, sosial, pendidikan, dan budaya.

Suku Dayak adalah penduduk asli Kalimantan Tengah yang sebagian besar tinggal di pedalaman hutan belantara Kalimantan Tengah Suku Dayak terbagi lagi menjadi beberapa sub-sub suku dayak dan diantara sub-sub suku ini dipisankan oleh kondisi geografis yang sulit dijangkau. Setiap sub-sub suku Dayak memiliki corak bahasa yang berbeda satu dengan yang lainnya. Corak pluralisme suku Dayak yang terbagi lagi dalam beberapa sub suku ini memberikan gambaran bahwa suku Dayak bukan merupakan sebuah kelompok etnik yang homogen. Riwut (1956) membuat pembagian suku Dayak menjadi delapan belas suku untuk seluruh Kalimantan, yang terbagi menjadi 403-450 suku kecil pengelompokan ini berdasarkan: 
(1) Ngaju Group, yang terbagi atas empat suku besar, $=$ Ngaju Terdiri atas 53 suku kecil

= Maanyan Terdiri atas 8 suku kecil = Lawangan Terdiri atas 21 suku kecil = Dusun Terdiri atas 8 suku kecil

(2) Apau Kayan Group, yang teragi atas tiga suku besar, = Kenyah

= Kayan

Terdiri atas 24 suku kecil

= Bahau

Terdiri atas 10 suku kecil

Terdiri atas 26 suku kecil

(3) Iban Group, yang terdiri atas sebelas suku kecil.

(4) Klemantan, yang terbagi aatas dua suku besar, yaitu = Klemantan Terdiri atas 47 suku kecil = Ketungau Terdiri atas 39 suku kecil

(5) Murut Group, terbagi atas tiga suku besar,

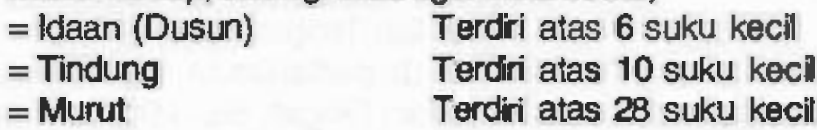

(6) Punan Group, terdiri atas tiga suku besar,
= Basap
$=$ Punan
Terdiri atas 20 suku kecil
$=$ At
Terdiri atas 24 suku kec:
Terdiri atas 5 suku kecil

(7) Ot Danum Group, terdin atas 61 suku kecil

Suku Dayak menggunakan garis ke turunannya didasarkan pada garis keturunan Patrilineal, yang dihitung dari garis keturunan laki-laki. Sebagian besar suku dayak menyandarkan kehidupannya kepada pertanian, ladang berpindah-pindah, buruh di hutan dan berburu. Namun bagi sebagian masyarakat Dayak yang tinggal d Kota, mereka menjadi pegawai negeri (PNS) dan sebagian lagi berdagang. Kepercayaan agama Suku Dayak adalah "Kaharingan", yaitu penghormatan pada roh nenek moyang atau pemujaan roh-roh leluhur yang berkaitan dengan unsur-unsuranimisme-dinamisme.
Sebagian masyarakat suku Dayak lainnya banyak yang memeluk agama islam dan Kristen. Sekalipun mereka memeluk agama selain dari agama Kaharingan (awal mula agama suku Dayak), tanpa sadar suku dayak masih memperliha tkan adanya pengaruh unsur-unsur kebudayaan Kaharingan Seperti percaya tentang adanya Mandau (senjata khas suku dayak) yang panas karena banyak digunakan untuk membunuh orang, tentang adanya kambe (hantu), tentang kekuatan kaji(aji-ajh), dan lain-lain, walaupun di lain pihak ada yang mengungkapkan bahwa hal-hal yang 
demikian adalah sesuatu yang ada kaitannya dengan setan (Kusni, 2001).

Tradisi dan adat istiadatjaman dahulu yang berpegang teguh pada unsur-unsur gaib masih sangat diyakini dan dijalankan untuk kelangsungan kehidupan mereka. Pola pikir tradisional masih sangat melekat dalam kehidupan masyarakat Dayak, seperti percaya pada mimpi bunyi bu rung tertentu sebagai pertanda kematian, ular melintasi jalanan, pohon kayu yang tumbang. Unsur alam sangat dipercaya dapat memberikan petunjuk untuk menghilangkan kesangsian diri atau keraguan dalam melaksanakan aktifitas sehari-hari, misalnya ketka hendak bepergian keluar rumah, biasanya terlebih dahulu melihat ke udara mencari keberadaan burung Antang(burung yang danggap memiliki makna mistik). Keberadaan burung Antang, cara terbang, menjurus lurus atau berkeliling memutar, mempunyai arti dan petunjuk untuk menjalankan segala aktivitas mereka (Surata \& Andrianto, 2001).

Pada masa lalu masyarakat Dayak mengenal lembaga budaya Mengayau (kayau) dan Mangkok merah. Mengayau (kayau) berarti mencari atau memotong kepala manusia dengan motif balas dendam atau memotong kepala musuh dalam keadaan perang sebagai simbol kepahlawanan. Sementara Mangkok merah adalah sarana komunikasi yang digunakan untuk menjalin solidaritas etnis, khususnya yang berkaitan dengan peperangan (Sihbudi, dkk. 2001).

Berkembangnya masyarakat multikultural dalam masyarakat Kalimantan Tengah adalah konsekuensi dari modernisasi dan globalisasi yang didalamnya turut membonceng arus urbanisasi dan migrasi, oleh karena itu memahami secara komprehensif dinamika sosial dan pola hubungan antar kelompok etnik yang bermukim di Kalimantan Tengah menjadi sangat relevan dan memiliki sumbangan yang sangat berarti, tidak saja sebagai dasar untuk memahami kejadian atau upaya untuk menyusun pola penyelesaian pasca konflik secara matang, tetapi juga sebagai kritik terhadap berbagai anggapan yang sangat sempit dan keliru tentang etnisitas dan sistem integrasi nasional yang selama ini dikembangkan negara ini.

Disamping suku Dayak, kelompok etnis lain yang cukup dominan d Kalimantan Tengah adalah suku Banjar. Begitu dominannya suku Banjardalan kehidupan masyarakat Kalimantan Tengah, digambarkan dengan digunakannya bahasa Banjar sebagai bahasa komunikasi sehari-hari antar kelompok etnis, baik itu suku Banjar sendiri, Dayak, Bugis, Jawa, Arab, dan Madura. Bahasa Banjar menjadi bahasa pemersatu, selain bahasa Indonesia, dalam pergaulan sosial an tar masyarakat etnis di Kalimantan Tengah. Mata pencaharian suku Banjar sangat beragam, mulai dari buruh, tukang ojek, jual sayur, berdagang, sampai pegawai negeri (PNS). Sementara dari segi kepercayaan keagamaan, mayoritas masyarakal suku Banjar menganut agama Islam yang taat dan fanatik, kohesivitas kesukuan berkembang berdasarkan semangat keagamaan Islam yang kuat, terutama melalui berbagai kegiatan-kegiatan keagamaan. Disamping hubungan ekonomi, Ikatan keagamaan-lah yang sering mempertemukan semangat persaudaraan antara suku Banjar dengan suku Dayak muslim, Bugis, Jawa, Arab, dan Madura.

Di samping suku Banjar, etnis Cina adalah kelompok kecil yang dominan secara ekonomi di Kalimantan Tengah. Sektor ekonomi informal seperti perdagangan, sentra-sentra industri kecil dan besar banyak dikuasai etnis Cina. Pola hubungan sosial antara etnis cina dengan etnis-etnis lain di Kalimantan Tengah lebih didasarkan kepada saling ketergantungan (interdepedensi) kepențingan secara ekonomi. Sementara 
Etnis Bugis yang tba d Kalimantan Tengah melalui migrasi swakarsa dan program trasmigrasi yang dikelola pemerintah menempati beberapa "daerah trans" yang telah dipersiapkan oleh pemerintah yang tersebar diseluruh wilayah Kabupaten di Kalimantan Tengah. Etnis Bugis berkelompok dalam wilayah tertentu, bahkan perkampungan mereka yang berada di lokasi trasmigrasi dikenal dengan sebutan "kampung Bugis". Sebagian besar mata pencaharian suku Bugis di Kalimantan Tengah adalah buruh hutan atau menebang kayu, petani, berdagang, dan nelayan.

Berbeda dengan etnis Bugis yang jumlahnya terbatas, etnis Jawa di Kalimantan Tengah juga termasuk golongan dominan. Etnis Jawa hampir tersebar diseluruh wilayah Kalimantan Tengah yang mayoritas tiba di Kalimantan Tengah melalui program transmigrasi pemerintah dan sebagian lagi migrasi swakarsa. Mata pencaharian etnis ini juga sangat beragam, mulal dari buruh, penebang hutan, petani, berdagang, barkan adajuga yang menjadi pegawai negeri (PNS). Sama dengan etnls Bugis, di Kalimantan Tengah juga terdapat perkampungan etnis Jawa yang dikenal dengan sebutan "kampung Jawa" seperti di Kota Sampit ibukota Kabupaten Kotawaringin Timur.

Salah satu kelompok etnls yang lumayan besar jumlahnya dan dominan pengaruhnya adalah etnis Madura. Migrasi etnis Madura pertama kall ke Kalimantan telah terjadi pada abad ke-13, tetapl puncaknya berlangsung pada akhir abad ke19 dan awal ke 20. kelompok etnik ini hidup dari usaha pertanian dan sektorl informal perkotaan, terkonsentrasinya mereka pada bidang tersebut karena rata-rata memiliki tingkat pendidikan rendah, bahkan tidak sedikit yang buta huruf (Sudagung, 2001). Begitu besar pengaruh etnik Madura yang mempunyai etos kerja tínggi dan lambat laun sernakin membesar jumlahnya di Kalimantan
Tengah, sehingga dalam kehidupan sosial ekonomi, kelompok etnik ini mampu mengambil alih tatanan sosial-ekonomi yang sebelumnya di dominasi kelompok etnik lain, termasuk etnis Dayak.

Seperti halnya etnis dayak etnis Madura menganut sistem kekerabatan berdasarkan garis ayah maupun bu (patemal and matr. na' relatives). Tetapi pada umumnya, unsur bapak atau laki-laki begitu domlnan pengaruhnya dalam kehidupan keluarga (Wiyata, 2002). Solidaritas kelompok etnik Madura sangat kuat, hal ini dapat dilihat dari pola pemukiman masyarakat madura yang dikenal dengan sebutan Kiampong Meiji dan Taneyan lanjeng. Kampong Meiji, kumpulan atau kelompok pemukiman penduduk desa yang satu dengan desa yang lain sallng terisolasi. Menurut Wiyata (2002), antropolog budaya asal madura:

\begin{abstract}
"Konsekuensi sosial dari kedua pola pemukiman ini adalah terbentuknya solidaritas internal antar masing-masing anggota atau penghuninya menjadi sang a kuat. Apabila terjadi pelecehan terhadap salah seorang anggota keluarga maka selalu dimaknai sebagai pelecehan harge diri teithadap semua keluarga. Lebih-lebih jika pelecehan tersebut menimpa anggota keluarga perempuan (istri). Jika hal Inl terjadl maka semua anggota keluarga dalam pemukiman tersebut akan bereaksi. Reaksi yang muncul pada suami yang istrinya dilecehkan (diganggu) selalu dalam bentuk tindakan kekerasan atau carok, yang pasti akan didukung oleh semua anggota keluarga lainnya sebagai bentuk reaksi mereka"
\end{abstract}

Fenomena terbentuknya solidartas etris Madura yang berada diperantauan, menu rut Wiyata (2002) karena etnis Madura di perantauan secara soslologls menjad kelompok minoritas, maka salah satu cara untuk mempertahankan eksistensi sosialnya adalah dengan mempererat solidaritas sosial d kalangan mereka. Akibatnya, jika salah satu diganggu atau dilecehkan, akan 
cepat berpengaruh kepada yang lain. Menurut Sudagung (2001), Ikatan sosial yang menyatukan orang Madura adalah persamaan terrp at tinggal. $\mathrm{Hal}$ ini diperkuat dengan kenyataan bahwa d perantauan orang Madura bertempat tinggal secara mengelompok di dalam satu pemukiman yang sama, oleh karenanya ikatan sosial orang Madura diluar daerah etnisnya atau ditanan rantau menjadi lebih kuat. Ada empat ingkatan solidaritas dalam diri individu terhadap sau kelompok etnis; (1) Solidaritas sedarah atau keluarga; (2) Solidaritas kedaerahan; (3) Solidaritas kesukuan, (4) Solidaritas kebangsaan atau nasional.

Keuletan dan etos kerja yang tinggi dalam masyarakat Madura terlihat pada prinsip kar-karkar-col,pek, . yaitu peribahasa yang menggambarkan karakter seperti ayam, yang mencakar-cakar rezeki, sedikit demi sedikit, dikumpulkan hingga menjadi banyak. Masyarakat Madura menerapkan prinsip itu dengan kuat. Sementara bagi ofang Madura yang merantau, ada desakan kuat dari lingkungan internal untuk selału berhasil, sehingga implikasi dari prinsip ini membuat etnik Madura makin tekun dan ada kecenderungan orang Madura selalu sukses di perantauan (Wiyata, 2002).

Sama halnya dengan budaya Kayau Mengkayau (memotong kepala) dan mangkok merah (membangun solidaritas) yang berlaku dalam kebudayaan etnis Dayak. Etnis Madura juga mempunyai lembaga budaya yang disebut dengan Carok, yaitu membunuh musuh yang dianggap telah melecehkan dan menghina harga diri orang Madura. Carok dalam pandangan masyarakat Madura tidak dilihat sebagai tindakan kriminal semata, akan tetapi sebuah tindakan kewajaran bahkan menjadi sebuah kewajiban yang harus dilakukan untuk menjaga martabat dan kehormatan dirl, menjaga dari rasa todus (malu), yaitu perasaan terhina karena merasa dilecehkan harga dirinya. Duel sampai mati ini justru menjadi perilaku kultural demi mempertahankan tatanan sosial yang terganggu atau terancam, baik dalam konteks individu maupun komunitas. Seperti mengganggu istri orang adalah masalah individual, tapi pada akhirnya menjadi masalah sosial karena mengganggu tatanan keluarga yang notabene bagian dari tatanan sosial yang lebih luas. (Wiyata, 2002). Proses akulturasi dalam pergaulan sosial masyarakat multi-etnik di Kalimantan Tengah juga ditandai dengan adanya saling ketergantungan (interdepedensi) secara ekonomi antar kelompok etnik dan fenomena kawin campur (cross maried) antarpasangan kelompok etnik yang berbeda baik Dayak, Madura, Banjar, Jawa, Cina, maupun Bugis.

Etnis Madura yang bermukim di Kalimantan Tengah dalam konteks identitas etnik (menunjuk pada faktor genealogis dan penguasaan bahasa Madura sebagai lingua franca) menurut Wiyata (2002), dapat dibedakan menjadi dua kelompok, yaitu:

Kelompokpertama, adalah orang Madura yang lahir dan dibesarkan di Kalimantan, baik sebagai keturunan/generasi kedua maupun generasi ketiga dari orang tua mereka sebagai perantau pertama kali. Dengan kata lain, pengungsi secara genealogis merupakan keturunan langsung orang Madura yang sudah bermigrasi ke sana sejak sebelum kemerdekaan. Seiring dengan bejjalannya proses waktu perartauan yang panjang, identitas etrik orang Madura di Kalimantan Tengah dilihat dari aspek kemampuan atau penguasaan bahasa Madura sudah tidak tampak lagi. Bahasa yang di pergunakan dalam pergaulan sosial sehari-hari selama di daerah rantau adalah bahasa Banjar dan Dayak. Dilihat dari konteks historisnya, akarsejarah keberadaan warga Madura selama berada d Kalimantan Tengah telah mencapai tiga bahkan empat 
generasi dan berbaur secara alamiah dengan warga lokal sudah ratusan tahun.

Kolompok kedua, adalah orang Madura yang karena faktor genealogis dapat disebut sebagai etnik Madura Pendhalungan, karena mereka lahir dan dibesarkan di wilayah Madura dan baru beberapa tahun sebelum meletusnya konflik sosial pergi merantau ke Kalimantan Tengah. Fenomena ini juga tidak terlepas dari arus globalisasi dan kemajuan teknologl transportasi ke daerah Kalimantan Tengah yang hanya ditempuh dalam waktu sehari semalam. Kelompok kedua ini kendati sangat kecil jumlahnya akan tetapi telah membawa perubahan fundamental dalam tatanan kehidupan masyarakat.

\section{ANATOMI KONFLIK KOMUNAL. DAN SEJARAH PERTIKAIAN ETNIS DI KALIMANTAN TENGAH}

Salah satu persoalan sentral dalam masyarakat majemuk adalah terciptanya proses akulturasi antar kelompok etnik. Konsekuensi dari akulturasi dan proses interkasi sosial kelompok etnik yang memiliki latar sosio-kultur yang berbeda ini seringkali menimbulkan persinggungan, keteganganketegangan, dan konflik, antar kelompok yang dapat dipicu olsh berbagai persoalan. Masyarakat majemuk muncul sebagai konsekuensi berbagai peristiwa dan perubahan sejarah seperti, Migrasi, kolonisasi, dan penbentukan sebuah negarabangsa (nation-state) (Berry, dkk. 1995). Masyarakat majemuk menurut Horowitz, dalam Ethnicity Group in Confict (1985), adalah masyarakat yang terdiri dari dua atau lebih elemen dan talanan sosial yang hidup bersama-sama secara berdampingan, namun tidak terintegrasi dalam satu kesatuan politik. Konflik dalam masyarakat majemuk yang di dalamnya tidak ada unsur kebudayaan dominan menaungi unsur-unsur budaya etrik lain sebagai pembauran (melting pon) dalam pergaulan sosial antar masyarakat etrik, seperti d Kalimantan Tengah sangat riskan dan mudah terjadi konflik.

Selain akibat gesekan kultural yang menyebabkan terjadinya berbagai kerusuhan sosial antar kelompok etnik di Kalimantan Tengah, faktor lain yang ikut menjadi penyebab terjadinya tragedi kemanusiaan tersebut, adalah faktor struktural, politik, sosial, dan ekonomi. Diperlukan satu kerangka pemahaman yang komprehensif dan aril dalam melacak sumber konflik, anatoml konflik, dan penyebab konflik etnis yang terjadi d Kalimantan Tengah.

Konflik sosial bernuansa etnis yang terjadl pada pertengahan Februari 2001 antara etnis Dayak dan Madura, pad a mulanya terjadi di Kota Sampit ibukota Kabupaten Kotawaringin Timur, kemudian secara drastis merambat ke Palangkaraya, Kuala Kapuas dan hampir seluruh wilayah Kalimantan Tengah. Konflik sosial bernuansa etnls ini telan menelan ribuan korban jwa dan harta benda yang tak temilai harganya. Seluruh aset dan harta benda etnis Madura, sebagai suku pendatang ludes dalam tempo hitungan harj. Social cost yang harus dibayar akibat konflik etris in disamping meninggalkan ribuan koban iwa, perasaan traumatik yang rnendalam bagi para koban, juga menimbulkan terlantamya ratusan ribu pengungsi yang kinl terusir ke beberapa daerah di Jawa Timur, khususnya Pulau Madura. Tidak ada yang menyangka, jika keharmonisan dan kerukunan yang terbangun selama itu menyimpan bara amarah dan api permusuhan yang sangat begitu mudahnya disulut ke permukaan. Memutuskan hubungan kekeluargaan, persaudaraan, dan rasa kebersamaan yang telah terjalin ratusan tahun yang silam.

Korban kerusuhan sosial di Kalimantan Tengah, yang akhirnya menjadi pengungsi internal atau internally displaced person (IDP), tidak saja dapat ditemukan d wilayah 
Pulau Madura, melainkan juga tersebar d beberapa wilayah Jawa Timur (Jatim), terutama di kawasan "Tapal Kuda", seperti Jember, Pasuruan, Situbondo, Bondowoso, Lumajang, Probolinggo, dan Banyuwangi. Menurut data statistik, sampai dengan 31 Desember 2001 jumlah pengungsi ini sekitar 125.969 jwa atau 31.398 kepala keluarga (KK). Dari jumlah ini, hanya sebagian kecil yang berasal dari Aceh, Maluku, dan Timor Timur (Wiyata, 2002).

Konffik antar etris seningkali berawal dari permasalahan individu kelompok etnis dengan kelompok etnis lainnya. Menurut Sudagung (2001), alasan bahwa konflik etnis yang terjadi di Kalimantan dipicu oleh persaingan dalam memperebutkan sumber sosial-ekonomi adalah pendapat yang tidak tajam karena kenyataanya sumber-sumber ekonomi di Kalimantan masih melimpah. tergantung kepada upaya kelompok masyarakat untuk memperoleh atau mengelolanya.

Konflik etnis di Kalimantan Teng ah juga bermula dari permasalahan individu antara anggota kelompok etnis Dayak dan Etnis Madura. Banyak versi yang menguraikan tentang penyebab terjadinya pertikaian berdarah antara etnis dayak dan Madura. Surata \& Andrianto (2001) memaparkan tentang pencetus terjadinya konflik etnis d Kaimantan Tengah;

"Kerusuhan Sampit bermula dari perkelahian seorang Siswa SMK Baamang. Perkelahian itu melibatkan anak warga Dayak dan Madura. Dimana pada hari minggu, 18 Pebruari 2001, pukul 03.00 (dini harl) sekelompok pemuda Dayak menyerang dan membunuh Matayo (warga Madura) dan tiga orang anggota keluarganya ikut tewas. Empat jam kemudian pasca oksekusi terhadap Matayo int, setelah informasi menyebar dipenjuru kota sampit, ratusan etris Madura berhamburan keluar dengan senjata tajam menuntut balas dan tidak terima terhadap kematian Matayo" (hat: 95).
Tindakan anarkhis dan Iuapan emosi etnis Madura dengan sasaran etnis Dayak yang ada di Kota sampit inilah yang pada akhirnya memancing solidaritas etnis dayak dari berbagai penjuru pelosok Kalimantan Tengah berhamburan menuju kota Sampit (lihat Kompas 21 Pebruari 2001). Sebagai anggota kelompok etnik, individu mempunyai keterikatan dengan kelompok etniknya. Rasa keterikatan dan kepedulian yang tinggi terhadap kelompok etris terjadi karena terkondisi oleh rasa saling memiliki yang pada gilirannya melahirkan rasa pembelaan yang tinggi pada kelompok etniknya atau etnosentrisme (Berry, dkk, 1995).

Faktor pemicu dalam kerusuhan sosial antara etnis Dayak dan etnis Madura tahun 2001 di Kalimantan Tengah,secarakronologis terjadi dalam tiga fase. Fase pertama, bermuia dari perkelahian antara pemuda dayak dan pemuda Madura di kompfeks lokalisasi Kerengpangi yang menyebabkan meninggalnya, Sendong anak salah seorang tokoh Dayak berpengaruh di daerah tersebut. Terbunuhnya Sendong ini menjadi pemicu konflik etnis tahap pertama yang menefan korban ratusan jwa dari etnis Madura di daerah Kerengpangi dan sekitamya. Fase kodua terbunuhnya seorang tukang ojek dari etnis Madura d perkampungan etnis Dayak (Desa Ranting tada). Fase ketiga, terbunuhnya tiga orang etnis Madura di kota sampit oleh sekelompok pemuda dari etnis Dayak, yang diduga bemotif balas dendam.

Faktorpemicu lainnya yang mempenuncing dan memperluas area konflik etnis di Kalimantan Tengah antara lain:

1. Beredamya isu bom di mana-mana, yang memancing ketegangan d kota sampit.

2. Berbagai macam tindakan kriminal yang melonjak drastis dan cenderung dibiarkan oleh aparat keamanan.

3. Pemyataan-pemyataan dari para tokoh informal kedua belah pihak yang saling menyalahkan. 
4. Lambannya aparat keamanan mengantisipasi terjadinya konflik dan pemicu yang sebelumnya sudah dirasakan oleh kedua kelompok yang bertikai.

5. Tekanan den tindakan aparat keamanan dalam menangani massa yang sedang marah dirasakan tidak adil bagi pinakpihak yang bertikai.
Menurut Stbudi dkk (2001) bahwa secara anatomik, kerusuhan sosial yang terjadi di berbagai daerah dewasa ini, merupakan keterkaitan yang saling berhubungan antar ketiga faktor, yaitu sumber masalah, faktor akselator, dan faktor pemicu Berikut ini adalah skema anatomi konflik etnis di Kalimantan Tengah berdasarkan ilustrasi pemikiran Sinbudi dkk (2001).

\section{Anatoml Kerusuhan Etnis Di Kalimantan Tengah (Akar masalah, akselerator, dan pemicu kerusuhan)}

\begin{tabular}{|c|c|c|}
\hline Sumber Masalah & Akselerator & PemicuPenyebab \\
\hline $\begin{array}{l}\text { Konflik kultural antara etnik } \\
\text { Dayak dan Madura yang sudah } \\
\text { larna belangsung. }\end{array}$ & $\begin{array}{l}\text { Berkurangnya daya dukung ling- } \\
\text { kungan bagi masyarakat asill } \\
\text { (Dayak) seperti tanah yang ler- } \\
\text { cemar, penebangan hutan secara } \\
\text { liar, krisis ekonomi, kemiskinan, dil. } \\
\text { Pergeseran sumber-sumber } \\
\text { ekonomi vial oleh pendatang. } \\
\text { Segregasi permukinan antara pen- } \\
\text { duduk asii dan pendatang yang } \\
\text { melebar. }\end{array}$ & 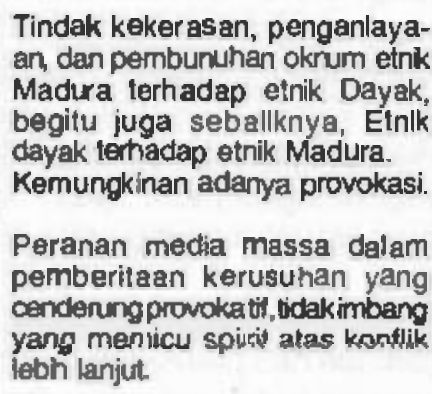 \\
\hline $\begin{array}{l}\text { Akumutasl tindak kekerasan } \\
\text { antaretnik Dayak dan etnlk } \\
\text { Madura. }\end{array}$ & $\begin{array}{l}\text { Terganggunya interakasi antar } \\
\text { etrik. Model lebih berciri lo dalam } \\
\text { bukan keluardan prasangka lebh } \\
\text { tinggi di bardingkan hamonisasi. }\end{array}$ & $\begin{array}{l}\text { Ponyebaran isu melalui berbagai } \\
\text { medla, baik tu telepon, maupun } \\
\text { informasi langsung, yang me- } \\
\text { nyesatkan. }\end{array}$ \\
\hline \multirow[t]{3}{*}{$\begin{array}{l}\text { Hubungan Antar Etnik lebih } \\
\text { berbentuk rivalitas dan konflik. }\end{array}$} & $\begin{array}{l}\text { Ketidaktegasan aparal keamanan } \\
\text { terhadap premanisme yang } \\
\text { merajalela, tindak kekerasan, dan } \\
\text { pembunuhan yang dikakukan oleh } \\
\text { ołnum etris Madura. }\end{array}$ & $\begin{array}{l}\text { Pemyataan tokoh-okoh informal } \\
\text { kedua belah pihak yang saling } \\
\text { mengancam dan menambah } \\
\text { ketegangan. }\end{array}$ \\
\hline & $\begin{array}{l}\text { Lambannya aparal keamanan dan } \\
\text { birokrasi dalam menangani konflk } \\
\text { antaretnik. }\end{array}$ & $\begin{array}{l}\text { Beredar lsu adanya bom-bom } \\
\text { yang disimpan beberapa oknum } \\
\text { etnis Madura. }\end{array}$ \\
\hline & $\begin{array}{l}\text { Ketidalpastian penegasan hukum } \\
\text { atau hukum tidak ditegakkan } \\
\text { sebagaimana mestinya. }\end{array}$ & \\
\hline
\end{tabular}

Sumber : Dlsarikan dari anatomi kerusuhan Sambas, Kalimantan Barat (Sihbudi, dkk. 2001) 


\section{SEJARAH PERTIKAIAN ETNIS DI KALMANTAN TENGAH}

Sejarah pertikaian antar etnis atau ber. bagai bentuk kekerasan antara etris Dayak dan Madura memang sering terjadi. Di samping beberapa sejarah kekerasan yang paling monumental lainnya, seperti Rapat Besar Tumbang Anoi. Konflik sosial yang terjadi di Kalimantan tengah, adalah konflik terbesar di Kalima tan pasca perjanjian Perdamaian Tumbang Anoi 1894 antar suku Dayak se-Kalimantan, yang merespon terjadinya konflik saudara antar suku-suku sesama masyarakat Dayak dan masyarakat Dayak dengan kaum penjajah Belanda (VOC).

Perjanjian perdamaian dalam Rapat Besar Tumbang Anoi tahun 1894 yang terletak di sungai kahayan Hulu Utara Kalmantan Tengah adalah upaya membangun kesepakatan damai antara suku-Suku Dayak yang sering terlibat perang suku (Asang Maasang), mengantisipasi banyaknya pembunuhan dan balas dendam (Bunu Habunu), dan maraknya kebiasaan membun manusia dengan memotong kepalanya untuk koleksi pribadi sebagal simbol kepahlawanan (Kayau Mengayau). Rapat Besar Tumbang Anoi ini juga menjadi mediasi diplomasi politik untuk membangun kesepakatan damai antara kaum penjajah Belanda dengan Pasukan Barandar yang ferdiri dari pasukan prajurit Dayak, para Demang, pahlawan Banjar dan tokoh-fokoh masyarakat. Sejarah pertikaian etnik di Kalimantan Tengah mewarnai kehldupan sosial masyarakat Kalimantan Tengah.

\section{MELACAK SUMBER-SUMBER KONFLIK ETNIS DI KALIMANTAN TENGAH}

Konflik pada dasarnya fidak hanya berimplikasi pada sisi negatif, tetapi juga mempunyai makna positif dalam kehidupan bermasyarakat. Konflik dapat memacu idividu atau kelompok untuk memiliki semangat berkompetisi dan sebagai alat perekat kehidupan bemasyarakat, apabila dapaf dikelola dengan baik (Vieger, dalam Surata, 2001). Sebaliknya konflik dapat menjadi sumber biang malapetaka dan kehancuran kehidupan berbangsa ketika disertal dengan tindakan anarkhis dan kebrutalan seperti yang ferjadi pada konflik etnis di Kalimantan Tengah.

Pandangan teori konflik Marx, menilai terjadinya konflik of dalam masyarakat disebabkan oleh dampak dari struktur sosial yang tidak seimbang, kelompok pemilik modal melakukan eksploitasi terhadap kelompok kelas pekerja (Sihbudi, dkk 2001). Konflik etnis di Kalimantan Tengah berbenfuk konflik horizontal, dimana antara etnls Dayak dan etnis Madura berada pada posisi saling berhadap-hadapan dan bermusuhan. Ganesha (dalam Surata \& Andrianto, 2001) melihat konflik horizontal daiam masyarakat multi-etrik yang cendenung diwarnai kekerasan, penghancuran, pernbunuhan, bahkan pengusiran dapat dipicu oleh: pertama, saling mengklaim dalam menguasai sumber daya yang mulai terbatas akibat tekanan penduduk dan kerusakan lingkungan. Kedua kecemburuan sosial bersumber dari ketimpangan ekonomi antara kaum pendatang (migran) dengan penduduk lokal (asli), ketiga, adanya dorongan emosional kesukuan karena ikatan-ikatan norma-norma tradisional. Empat, tumbuhnya kesadaran kelompok subordinat tentang kepentingan kolektifnya dan kelima, adanya polarisasi diantara kelompok dominan dan subordinat.

Menurut perspektif kebudayaan, konflik kekerasan antar kelompok etnik ini menurut Wurianto (dalam Mulkhan, 2002) dapat dilihat sebagai suatu nilai yang diyakini masing-masing kelompok etnis sebagai kebiasaan (folkways), adat (custom) dan tradisi, yang terekam dalam ikatan nilai 
kebudayaan kelompok etnik dan cenderung menjadi sebuh community spirit, seperti kebudayaan Carok(membunuh karena harga din) bagi etnis Madura dan Kayau Mengayau (potong kepala), Mangkok merah (solidaritas etnis) dalam kebudayan etnis Dayak.

Menurut Riwanto (dalam, Sudagung, 2001), mengutip laporan Human Right Watch, 1997 dalam laporan tentang Comunal Conflict di Kalimantan Barat, memberikan tiga argumentasi yang menjelaskan latar belakang terjadinya konfik etris di Kalimantan. Pertama, argumentasi budaya (the cultural argument) yang menganggap bahwa perbedaan budaya antara kedua kelompok etnik, seperti penyelesaian persengketaan dengan cara kekerasan dan pertikaian berdarah dianggap sebagai alasan seringnya terjadi konflik antara kedua etnik, terutama Dayak dan Madura. Kedua, argumentasi marjinalisas! (the marginalization argument) mengungkapkan bahwa proses marjinalisasi yang dialami penduduk lokal (Dayak) akbat berbagai kebijakan pemerintah yang sangat merugikan penduduk asli sebagai akar resistensi perlawanan dari penduduk setempat temadap segala sesuatu yang berasal dari luar (termasuk pendatang etnis
Madura). Ketiga, argumentasi manipulasi politik, (the Political manipulation argument), yaitu suatu penilaian yang beranggapan bahwa faktor budaya dan sosial-ekonomi meskipun diakui berperan, tidak cukup kuat untuk mendorong terjadinya konflik etnik berskala besar seperti yang terjadi kota sampit, Kalimantan Tengah, apabila tidak ada pinak ketiga yang benusaha memanipulasi keadaan.

Menurut perspektif Psikologi Lintas Budaya, konflik etnis dalam masyarakat majemuk dapat dimaknai sebagai dampak stress yang meledak. Stressor yang muncul bersumber dari proses-proses akulturasi antar kelompok etnik yang mengalami kristalisasi. Berry, dkk (1995) menyebutnya dengan stress akulturatif, yaitu serangkaian perilaku stress yang terjadi akibat pengaruh sosial selama berlangsungnya proses akulturasi. Stress akulturatif inl ditandai dengan menurunnya stamina kesehatan fisik dan mental individu sebagai unit terkecil dari kelompok, baik secara biologis. psikologis, dan sosial seperti kecemasan. depresi, perasaan marjinalitas dan alienasi, aras simptom psikosomatis meningkat, dan kebingungan jati diri.

Tabel1

Hubungan antara akulturasi dan stress (dalam, Berry, 1992)

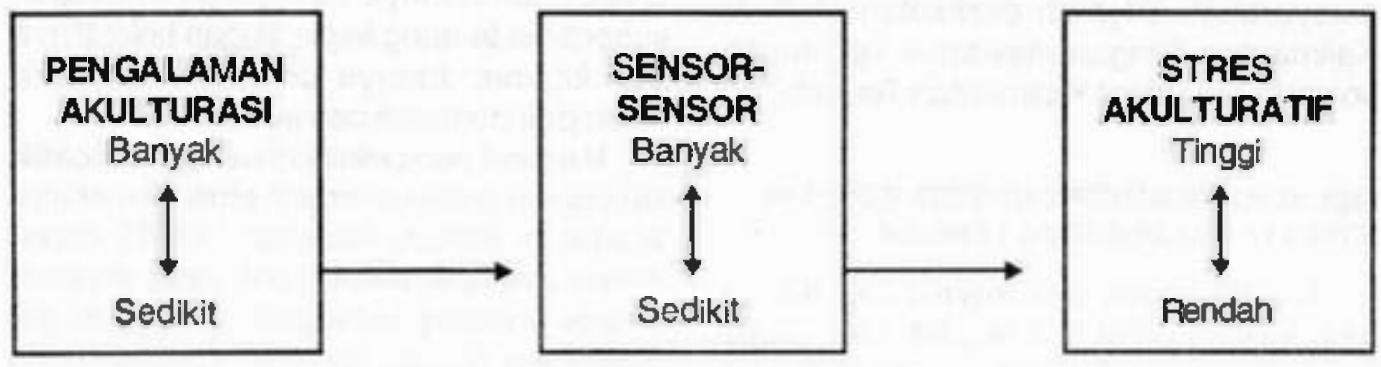


FAKTOR-FAKTOR YANG MEMERANTARAI HUBUNGAN ANTARA AKULTURASI DAN STRES

Modus akulturasi : Integrasi, Asimilasi, Separasi, Marjinalisasi

Fase akulkturasi : Kontak, Konflik, Krisis, Adaptasi

Keberadaan masyarakat yang lebih luas : Muttikultural lawan Asimilasionist:

Prasangka \& Diskriminasi

Ciri-ciri kelompok yang berakulturasi : Usia, Status, Dukungan Sosial

Ciri-ciri individu yang berakulturasi : Penilaian. Pengatasan, Sikap. Kontak

Sumber Psikologi Lintas-Budaya: Riset dan Aplikasi, oleh Berry, J.W, dkk, (1999).

H.C. Triandis seorang pakar psikologi sosial terkemuka, mengungkapkan bahwa konflik dan ketegangan yang terjadi antar kelompok disebabkan adanya kultur subjektif yang berbeda dan kegagalan dalam memahami masing-masing kultur subjektif. Kultur subjektif adalah cara khas suatu komunitas kultur atau golongan kebudayaan dalam memandang atau mempersepsi lingkungan sosialnya. Analisis kultur subjektif kelompok etnis sangat penting dilakukan sebagai upaya mereduksi konflik yang terjadi antara kelompok etnis. Studi cross cullureterhadap masing-masing komunitas kultur atau kelompok etnik bertujuan untuk menemukan landasan baru bagi semua pihak yang terlibat dalam konfllk untuk meningkatkan komunikasi, saling pengertian, dan memecahkan setiap persoalan dan kontlik melalui jalan negosiasi dan perdamaian (Wamaen, 2002).

Kekerasan yang dilakukan secara kolektif seperti konflik etnis Kalimantan Tengah, secara psikologis akan membangkitkan suatu rasa takut terhadap kelompok lain yang dijadikan sebagai sasaran dan juga dijadikan sebagai proses kristalisasi komitmen di kalangan anggota kelompok etnik. Individu atau anggota kelompok yang terlibat dalam konflik komunal akan larut dalam berbagai periaku dan individu tidak mampu lagi melakukan kontrol terhadap dirinya.

Gustave Le Bone seorang pakar psikologi massa, menyebutkan bahwa karakter suatu gerakan massa (collective mind) memiliki efek penularan yang cepat, para anggota kelompok (individual mind) tanpa sadar terbawa kedalam tindakan kelompok. Karakter jiwa massa (collective mino) ini lebih impulsif, lebih mudah tersinggung, tergesa-gesa, lebih mudah dipengaruhi (suggestability), mudah mengimitasi dan terprovokasi situas| dan lingkungan, (Gerungan, 1988). Masingmasing anggota kelompok etnis yang bertikai dalam konflik komunal d Kalimantan Tengah seakan-akan kehilangan identitas dirinya (jati diri) yang memiliki referensi nilainilai transedental dan kemanusiaan. Sernentara identitas kelompok (anonimity) yang muncul menggantkan identitas pribadi, sangat antagonistik dan menaburkan sikap in-groupdan out-groupberbasis kecurigaan dan prasangka sosial terhadap kelompok etnik lain.

Prasangka sosial sebagai suatu proses belajaryang paling umum adalah terbentuknya stereotipe berdasarkan sentimen etnis. Menurut Warnaen (2002) stereotipe etnis adalah kepercayaan yang bertahan yang berbentuk gambaran di kepala atau pre- 
konsepsi tentang orang-orang darigolongan etnis tertentu. Streotipe yang sudah lama melekat dalam pikiran seseorang ini lambat laun akan berubah sesuai dengan intensitas dan arah prasangka sosial yang dimiliki.

Prasangka sosial merupakan sikap perasaan orang-orang terhadep golongan manusia tertentu, golongan ras atau kebudayaan, yang berlainan dengan golongan orang yang berprasangka itu (Gerungan, 1988). Feldmen (1985) dengan bahasa yang berbeda mendefinisikan prasangka sosial sebagai evaluasi positif atau negatif atau sikap mengadili suatu anggota dari kelompok berdasarkan keanggotaanya pada kelompok tersebut. Peranan prasangka sosial dalam konflik etnis d Kalimantan Tengah sangat besar pengaruhnya dalam membentuk sikap antipati dan perrnusuhan antar etnis Dayak dan Madura. Sears dkk (1985) menjelaskan definisi prasangka sebagai penilaian terhadap suatu kelompok atau individu yang didasarkan keanggotaan kelompok orang itu, penilaian terhadap orang lain itu didasarkan kategori rasial dan tidak berdasarkan informasi atau faktortentang diri mereka sebagai individu.

Teori Psikodinamika menganalisa prasangka sebagai suatu hasil dari dinamika tertentu kepribadian individu. Prasangka dianggap sebagai agresi salah tempat (displaced aggressition) Saat seseorang marah atau frustrasi dia normal dan akan mengekspresikan agresinya terhadap sumber ketidakbahaglaannya, bla sumber gangguan tidak dapat diserang karena takut dia akan menempatkan agresi pada target lain (Dayakisni, 2001).

Seseorang yang berprasangka pada suatu kelompok (out-group) cenderung mengevaluași anggota-anggota kelompok sosial tersebut dia akan mengkritik nilai-nilai dan perilaku yang diterapkan dalam kelompok sosial tersebut karena tidak sesuai dengan nilai yang dianut kelompok- nya (In-group). Perasaan in-group sering menimbulkan "in-group bias" yaitu kecenderungan untuk menganggap bahwa kelompoknya lebih baik dari pada kelompok lain (out-group). In-group bias ini pada titik tertentu akan memunculkan pandangan etnosentrisme, etnis yang satu merasa dan menganggap dirinya lebih hebat, unggul, berhak daripada etnis lain

\section{RESOLUSI DAMAI KONFLIK ETNIK KALIMANTAN TENGAH}

Dua tahun sudah konflik etnik di Kalimantan Tengah berlalu. Semenjak itu pula konffik yang menelan ribuan orang dan harta benda yang tak ternilai harganya melawati tahap-tahap penting perkembangan pasca kontlik. Perkembangan terpenting pasca konflik adalah meretas jalan rekonsiliasi dan penyelesaian perdamaian dua entitas anak bangsa serta menyusun kembali puing-puing harapan guna merajut kebali mahligai kebersamaan. Banyaknya usaha penyelesaian konflik dalam setiap konflik sosial yang terjadi di Indonesia menemukan jalan buntu. Zartman (dalam Mial, 2000) berpendapat bahwa konfik yang terjadi dalam sebuah lingkungan sosial cukup matang bagi upaya perdamaian atau negosiasi, hanya jika berada dalam kondisi tertentu seperti "jalan buntu yang saling melukai". Suatu kondisi yang membuat kedua belah pihak yang bertikai harus menyadari bahwa tujuan tidak dapat tercapai dengan kekerasan, menyadari bahwa konsekuensi kekerasan memerlukan biaya kemanusian yang sangat besar. Altematif negosiasi menjadi pilihan terbaik yang strategis untuk menyelesaikan konflik.

Menurut Hendropuspito (1989), ada beberapa strategi penyelesain konflik sosial horisontal yang terjadi antar dua kelompok yang bertikai. Pertama, Konsiliasi atau perdamaian, yaitu suatu cara untuk 
mempertemukan pihak-pihak yang berkonflik guna mencapai kesepakatan bersama untuk berdamai yang akan dibantu pihak ketiga. Kedua, Mediasi yaitu suatu cara penyelesaian konfiik yang dibantu perantara (mediator). Mediator lebih bersifat koordinatif dan konsultatif, sementara materi kesepakatan dan aturan main dalam forum perdamaian tersebut ditentukan oleh kedua kelompok yang bertikai. Kitiga, Arbitrase atau penyelesaian melalui jalur pengadilan. Seorang arbiter (hakim) memberi keputusan yang mengikat kedua belah pihak yang bertikai. Keputusan hakim (arbiter) mengikat dan harus ditaati. Keempat, koersif (paksaan), yaitu cara penyelesaian konflik antar kelompok dengan mengunakan kekuatan atau paksaan fisik dan psikologis. Dalam hal ini lembaga yang mempunyai wewenang dan kekuatan untuk memaksa adalah negara. Kelima, detente, yaitu mengendorkan atau mengurangi hubungan ketegangan atau eskalasi konflik antara kedua kelompok yang bertikai melalui diplomasi politik.

Perubahan dari kondisi tidak matang kearah momentum yang matang pasca konflik, pada akhirnya dapat menghantar kedua kelompok yang bertikai kepada penyelesaian konflik. Momentum ini dapat dijadikan wahana proses identifikasi tujuan kedua belah pihak yang bertikai, perubahan kontekstual, pergeseran dalam persepsi, pola sikap, dan tingkah laku. Kematangan lewat transformasi konflik ini tidak datang secara tiba-tiba, tetapi merupakan sebuah proses transformasi yang kompleks dalam situasi tertentu, sebuah pergeseran dalam perilaku publik dan persepsi baru dan visi perdamaian diantara pembuatan keputusan kedua kelompok yang bertikai.

Masa transisi pasca konflik merupakan momentum yang penting untuk membuka komunikasi. Menggeser konflik menuju komunikasi dua arah membangun kesepakatan, dan membuka hubungan kerja same antara kedua belah pihak yang bertikai. Trijono (2001) mengungkapkan bahwa konflik horisontal dalam masyarakat sipil membutuhkan resolusi dan rekonsiliasi banyak jalur (multitrack). Beberapa langkah yang harus dirintis dalam masa transisi, $p e r-$ tama, meningkatkan kapasitas kelembagaan (institutional capacily building) di kubu kedua belah pihak dan pemerintah. Kedua, memfasilitasi terjadinya pertemuan dialogis kedua kelompok etnis yang melibatkan kedua tokoh lokal yang terlibat, baik ditingkat atas, menengah, dan bawah. Hal ini dilakukan untuk mencegah kebekuan komunikasi dan kebuntuan hubungan antar pihak yang berkonflik. Pertemuan ini perilu dilakukan seinformal mungkin, bersifat dialogis, partisipatif, berpijak pada proses yang menghargai insiatif dari pihak-pihak yang berkonflik dengan menciptakan iklim dialogis yang demokratis. Ketiga, Menindak lanjuti pertemuan dialogis itu dengan kegiatan mediasi ditingkat lokal. Hal itu dilakukan untuk menemukan pola penyelesaian secara kongkrit dan nyata, serta membangun kerangka pemahaman bersama kearah yang lebih teknis tentang jalan rekonsiliasi. Keempat, mendorong transis| dan transformasi konflik menunju rekonsliasi antara komponen masyarakat yang berkonflik, maupun yang tidak terlibat konflik. 


\section{Tabel2}

Pendekatan multi level dan multi jalur dari Lederach, 1998

(dalam Trijono, 2001)

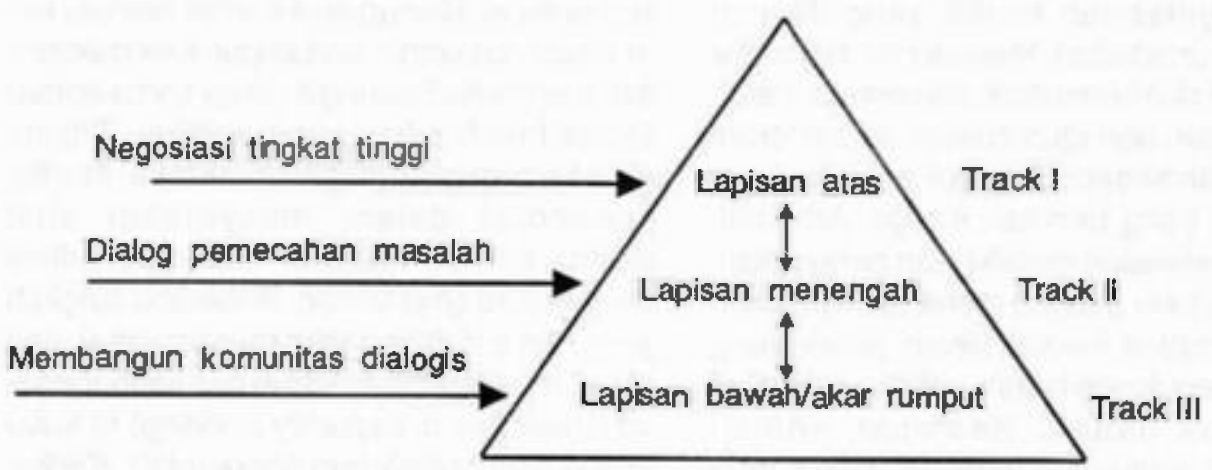

\section{Ditada,ofasf darf, Kohgrasan dan Kibm/ik, Tatitangan Bagi Demokrasi, Mwikhan, Tr/fon dktk(aOOOt)}

Transfromasi konflik bertolak dari penghargaan yang mendalam terhadap martabat kemanusiaan dan keunikan masing-masing kelompok etnik, serta berupaya menumbuhkan kesadaran akan nilai-nilai intrinsik dan kesadaran diri yang sehat. Fungsi mediasi menjadi signifikan sejalan dengan proses tranformasi konflik untuk menemukan jalan penyelesaian bagi kedua kelompok yang yang bertikai. Kraybill, dkk (2002) menentukan empat tahap yang harus dilakukan dalam mempertemukan pihak-pihak yang bertikai of meja perundingan.

Tahap pertama, menciptakan rasa aman pada kedua belah pihak. Di sini pertu dijelaskan penentuan aturan main atas prinsip saling menghargai, dan menyerahkan sepenuhnya kedua belah pihak secara suka rela dan tulus ikhlas mencarl kesepakatan bersama. Tahap keoua, Ajakan untuk saling memahami, yaitu masing-masing pihak diminta untuk memaparkan pandangannya tentang pertikaian yang terjadi, mengidentifikasikan aneka harapan dan keprihatian kedua belah pihak. Tahap ketiga, menciptakan rasa memiliki yaitu dengan jalan menjemihkan persoalan-persoalan, mengidentifikasi keprihatinan bersama dan menetapkan pijakan bersama. Tahapan ini juga dapat diharapkan menentukan langkah-tangkah konstruktif dan menunjukkan kemajuan yang berhasil dicapai. Tahap keempat, menentukan kesepakatan dan merumuskan pemecahan yang lestari. Memastikan bahwa kesepakatan yang dicapai bersifat adil serta melindungi martabat masing-masing pihak dan saling bertanggung jawab untuk memikul hasil kesepakatan yang diperoleh kedua belah pihak. 
Tabel3

Aneka Pendekatan dalam Mengatasi Konflik(Kraybill, 2002)

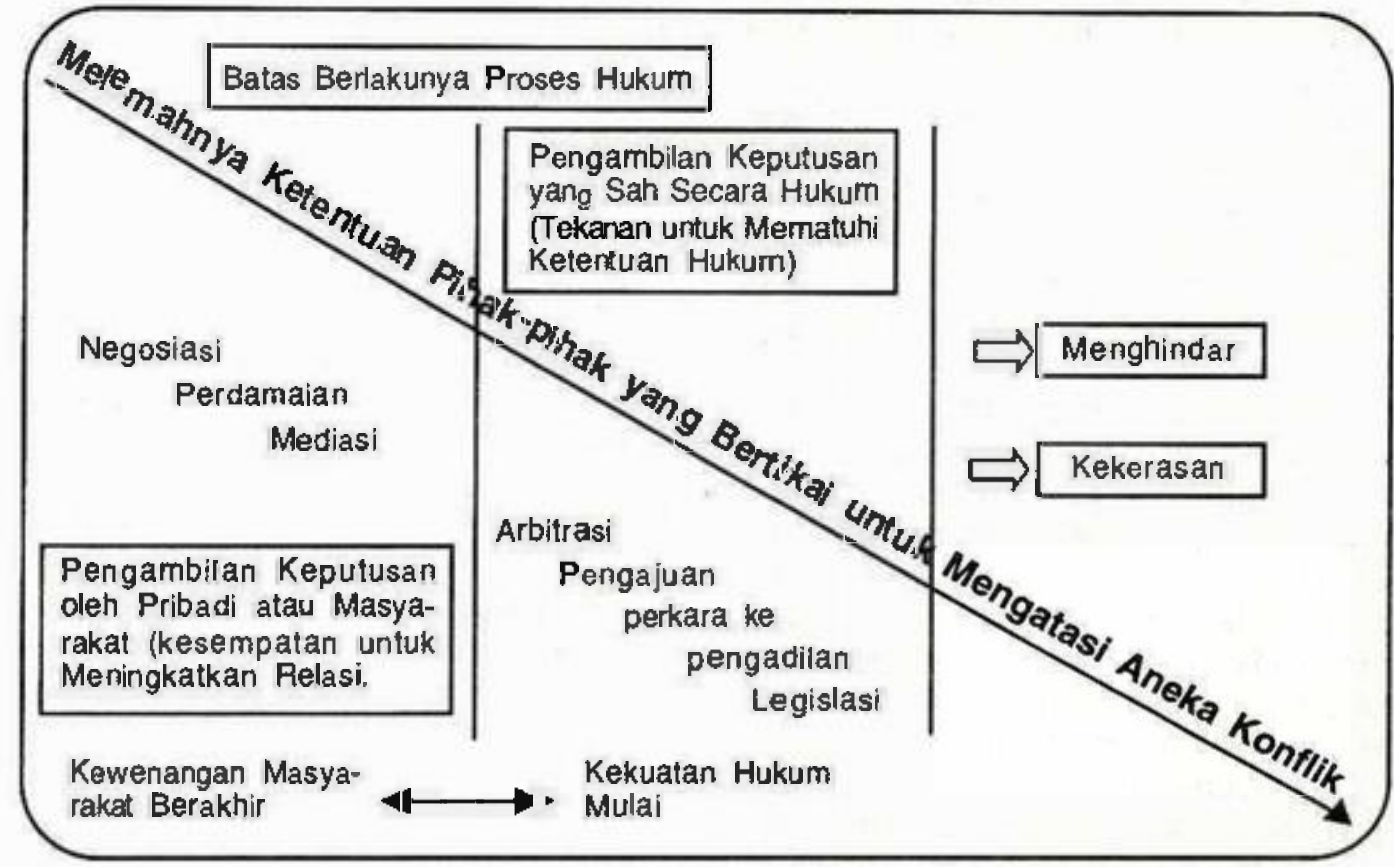

Diadaplasi dar Peace Skli: Panduan Medigior, Kraybli, R.S, dkk(diterjemahakan ojeh: 4 Suloralnys, PhD.), 2002

Menurut Hampson (dalam Miall dkk. 2000) Sebuah proses perdamaian dan rekonsiliasi dikatakan berhasil apabila mempunyai ciri-ciri sebagai berikut; Pertama, apabila proses rekonsiliasi tersebut memasukkan pihak-pihak yang ikut terpenganuh, dan pihak-pihak yang tampaknya akan menerima jika dilibatkan dalam proses rekonsiliasi tersebut. Kedua, perlunya membuat rumusan proses rekonsiliasi secara cermat, teliti, dan representatif. Ketiga, resolusi konflik hendaknya menawarkan sebuah keseimbangan antara komitmen dan fleksibilitas antar kelompok yang bertikai. Keempat, penyelesaian konflik atau rekonsiliasi hendaknya menawarkan insentif bagi pihak-pihak yang bertikai guna mempertahankan proses dan berpartisipasi dalam politik. Kolima, harus menyediakan penyelesaian pertikaian, mediasi, dan jika perlu renegoisasi ketika terjadi ketidaksepakatan. Keenam, hendaknya persoalan yang yang dibicarakan berhubungan dengan masalah inti dalam konflik dan menghasilkan sebuah transformasi nyata noma-norma dan prinsip-prinsip kerja sama yang membuat pihak-pihak yang tertibat menta'a tinya, persamaan hak, demokrasi dan pada saat yang sama menciptakan ruang polittik bagi negosiasi lanjutan dan akomodasi politik.

\section{PENUTUP}

Pandangan tentang konflik antar etnis di Kalimantan Tengah pertu dibedah dan rekonstruksi lebih teliti dan cermat, sebab pada kenyataannya dalam setiap konflik sosial bernuansa etnik tidak semua anggota 
etrik betul-betul berkonflik. Peleburan hubungan antar-etnis lewat lembaga perkawinan, kerja, dan saling ketergantungan secara ekonomi, politik, sosial, dan budaya menunjukkan adanya relasi simbiosis mutualisme antar-anggota etnis Dayak dan: Madura berlangsung cukup lama. Lebih tepat bila dika takan, bahwa anggota-anggota etnis Dayak sedang berkonflik dan bertikal dengan anggota etnis Madura, sehingga menimbulkan konflik sosial yang merambat ke seluruh tubuh etnis.

Pola pandang generalisasi dan ceroboh yang telah sekian kama merembes ke tubuh masyarakat kita, akan mudah dibakar suara-suara provokatif yang menghendaki kekacauan sosial dalam masyarakat Indonesia. Selain itu, yang perlu diwujudkan segera adalah penerapan hukum positif yang sungguh-sungguh menjamin keadilan sosial dan kesejahteraan sosial seluruh warga negara Indonesia. Kesenjangan sosial dan penerapan hukum yang berat sebelah hanya akan meningkatkan suhu konfllk soslal di masyarakat. Potensi perdamalan hanya akan diperoleh dalam konteks pertikaian etris di Kalimantan Tengah bia semua plhak memilikj kemauan untuk memperkaya simbolsimbol kesamaan. Kesamaan sebagai manusia, kesamaan sebagal anak bangsa, kesamaan cinta terhadap perdamaian, dan lain-lain. $\square$

\section{DAFTAR PUSTAKA}

Berry, J.W., dkk, 1999, Psikologi LintasBudaya: Riset dan Aplikasi, Gramedi Pustaka Utama. Jakarta.

Dayakisni, T, dan Hudaniah. 2001. Psikologi Sosial. UMM Press. Malang.

Feldman, R.S.1985. Social Psychology: Theories, Research and Application. New York: Mc Graw-Hill Book, Co.
Gerungan, W.A. 1988. Psikologi Sosial. Eresco. Bandung.

Harian Umum Kompas. Edisi Pebruari 2001Juli 2001.

Hendropuspito,D,OC, 1989. Sosiologi Sistematik. Kanisius Yogyakarta.

Kraybill, R.S., dkk, 2002, Peace Skill: Panduan Modiator, Kanlsilus, Yogyakarta.

Kusni, J.J. 2001. Negara Etnik: Beberapa Gagasan Pemberdayaan Suku Dayak. FUSPAD. Yogyakarta.

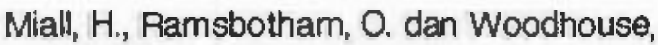
T, 2000, Resolusi Damai Konflik Kontemporer, PT Raja Grafindo Persada, Jakarta.

Mulkhan, A.M. dkk. 2001, Kekerasan dan Konflik: Tantangan Bagi Demokrasi, Forum LSM DIY, Yogyakarta.

Mulkhan, A.M. dkk, 2002. Membongkar Praktik Kekerasan Menggagas Kultur Nir-Kekerasan. Penerbit PSIF Universitas Muharnmadiyah Malang dan Sinergi Prees, Yogyakarta.

Riwut, T. 1956. Kalimantan Memanggil. Penerbit Endang. Jakarta.

Sears, D.O. Freedman, J.L. dan Peplau, L A. (diterjemahkan oleh Michael Adryanto). 1994. Psikologi Sosial Jilid 2. Penerbit Erlangga. Jakarta.

Sinbudi, R., Nurhasim, M., dkk. 2001, Kerusuhan Sosial of Indonesia: Studi Kasus Kupang, Mataram, dan Sambas. Grasindo, Jakarta.

Surata, A., dan Andrianto, T.T. 2001. Atasi Konflik Etnis, Global Pustaka Utama, Yogyakarta. 
Sudagung, H.S. 2001. Mengurai Pertikaian Etnis: Migrasi Swakarsa Orang Medura ke Kalimantan Barat, Penerit Institut Arus informasi, Jakarta.

Trijono, L. 2001. Keluar dari Kemelut Maluku: Relleksi Pengalaman Praktis Bekerja untuk Perdamaian Maluku. Pustaka Pelajar, Yogyakarta.
Warnaen, S. 2002. Stereotif Etnis dalam Masyarakan Multietnis. Penerbit Mata Bangsa, Yogyakarta.

Wiyata, A. L. 2002 Carok: Konflik Kekrasan dan Harga Diri Orang Madura, LKiS, Yogyakarta. 